\title{
Effects of deforestation on headwater stream fish assemblages in the Upper Xingu River Basin, Southeastern Amazonia
}

\author{
Paulo Ilha ${ }^{1,2}$, Sergio Rosso ${ }^{1}$ and Luis Schiesari ${ }^{3}$
}

The expansion of the Amazonian agricultural frontier represents the most extensive land cover change in the world, detrimentally affecting stream ecosystems which collectively harbor the greatest diversity of freshwater fish on the planet. Our goal was to test the hypotheses that deforestation affects the abundance, richness, and taxonomic structure of headwater stream fish assemblages in the Upper Xingu River Basin, in Southeastern Amazonia. Standardized sampling surveys in replicated first order streams demonstrated that deforestation strongly influences fish assemblage structure. Deforested stream reaches had twice the fish abundance than reference stream reaches in primary forests. These differences in assemblage structure were largely driven by increases in the abundance of a handful of species, as no influence of deforestation on species richness was observed. Stream canopy cover was the strongest predictor of assemblage structure, possibly by a combination of direct and indirect effects on the provision of forest detritus, food resources, channel morphology, and micro-climate regulation. Given the dynamic nature of change in land cover and use in the region, this article is an important contribution to the understanding of the effects of deforestation on Amazonian stream fish, and their conservation.

Keywords: Arc of Deforestation, Canopy, Land use, Ichthyofauna, Vegetation cover.

A expansão da fronteira agrícola amazônica representa a mais ampla mudança na cobertura e uso da terra no mundo contemporâneo, e ameaça a integridade de ecossistemas de riachos que abrigam a maior diversidade de peixes de água doce do planeta. Nosso objetivo foi testar as hipóteses de que o desmatamento afeta a abundância, a riqueza e a estrutura taxonômica de assembleias de peixes em riachos de cabeceira na bacia do alto rio Xingu, no sudeste da Amazônia. Por meio de amostragens padronizadas realizadas em riachos de primeira ordem, demonstramos que o desmatamento influencia fortemente a estrutura das assembleias de peixes. Riachos em áreas desmatadas tiveram o dobro da abundância de peixes que riachos em áreas florestadas. Essas diferenças na estrutura das assembleias foram em grande parte causadas pelo aumento na abundância de algumas poucas espécies, já que nenhuma influência do desmatamento na riqueza de espécies foi observada. A cobertura de dossel sobre os riachos foi o mais forte preditor da estrutura das assembleias, possivelmente por uma combinação de efeitos diretos e indiretos relacionados à provisão de detritos florestais, recursos alimentares, morfologia dos canais, e regulação micro-climática. Dada a natureza dinâmica da mudança na cobertura e uso da terra na região, este artigo é uma contribuição importante para a compreensão dos efeitos a longo prazo do desmatamento nos peixes de riachos amazônicos e, portanto, para sua conservação.

Palavras-chave: Arco do Desmatamento, Uso da terra, Cobertura vegetal, Dossel, Ictiofauna.

\section{Introduction}

Headwater streams are among the most threatened ecosystems on the planet (Sala et al., 2000; Millennium Ecosystem Assessment, 2005). Land cover change, in particular the conversion of natural landscapes for agriculture, is frequently pointed out as one of the main causes of their degradation. Land cover change influences stream ecosystems through multiple pathways: by directly and indirectly chan- ging channel morphology, by altering heat and light budgets mediated by canopy opening, by changing the partitioning of rainfall into evapotranspiration, infiltration and surface runoff, and by facilitating the erosion and transport of sediments, nutrients and contaminants (Helfman, 2007). As a consequence, several studies have evidenced strong impacts of land cover change on stream fish assemblages, suggesting it constitutes a critical challenge to the conservation of this relevant group (e.g., Dudgeon, 2000; Sutherland et al.,

\footnotetext{
${ }^{1}$ Departamento de Ecologia, Instituto de Biociências da Universidade de São Paulo, Rua do Matão, 321, Cidade Universitária, 05508-090 São Paulo, SP, Brazil. (PI) ilha@ib.usp.br, @ittp://orcid.org/0000-0003-3431-908X (corresponding author), (SR) serrosso2@ib.usp.br, (Dhttp://orcid.org/0000-0002-7310-9395

${ }^{2}$ Instituto de Pesquisa Ambiental da Amazônia, Rua Horizontina, 104, Centro, 78640-000 Canarana, MT, Brazil.

${ }^{3}$ Gestão Ambiental, Escola de Artes, Ciências e Humanidades da Universidade de São Paulo, Rua Arlindo Béttio, 1000, Vila Guaraciaba, 03828-000 São Paulo, SP, Brazil. 1schiesa@usp.br, @ohttp://orcid.org/0000-0003-0814-591X
} 
2002; Casatti, 2010; Casatti et al., 2015; Macedo, Castello, 2015; Leitão et al., 2018). However, little information about this issue exists concerning the Amazon Basin, where megadiverse areas are spatially congruent with areas of intense land transformation (but see recent work of Brejão et al., 2018, Leal et al., 2018, and Leitão et al., 2018).

The Amazon Basin harbors the most diverse freshwater ichthyofauna in the planet, with $\sim 2,500$ described species from an estimated total of 6,000-8,000 species (Reis et al., 2003; Lévêque et al., 2008). Approximately half of these species are expected to inhabit small headwater streams (Junk, Piedade 2004), which account to no less than three-quarters of total channel length in the basin (McClain, Elsenbeer 2001). Ichthyofaunas of headwater streams present high levels of endemism because of their comparative geographic isolation and limited species dispersal abilities (Junk, Piedade 2004; Nogueira et al., 2010). At the same time, headwater streams are intimately connected to the surrounding watershed and are therefore highly vulnerable to land cover change in general, and deforestation in particular. Twenty percent of the Amazonian closed-canopy forests were already converted into pastures and croplands, and it is expected that more than $50 \%$ will be converted or severely degraded by 2030 (Nepstad et al., 2008). The overwhelming majority of Amazonian land cover change $(\sim 85 \%)$ has occurred in the area known as the Arc of Deforestation, which correspond to the eastern, southeastern and southern edges of the Amazon Basin in the Brazilian States of Pará, Mato Grosso and Rondônia (Fig. 1; Nepstad et al., 2009), and encompass the Xingu River Basin.

The Xingu River is one of the largest tributaries of the Amazon River. It originates in the state of Mato Grosso and flows northward up to its confluence with the right-bank of the Amazon River in the state of Pará, draining 510,000 $\mathrm{km}^{2}$ and harboring one of the largest continuous mosaics of protected areas in the planet (ISA, 2012; Schwartzman et al., 2013). Twenty indigenous lands and ten conservation units form a $280,000 \mathrm{~km}^{2}$ forest corridor (Schwartzman et al., 2013). Even though much of the Xingu River Basin ( 55\%) and especially its large rivers are within these protected areas, most of its headwaters are in private land currently used for intensive agriculture (mainly soybean, but also corn and cotton) and cattle ranching (Panday et al., 2015). Knowledge on the biodiversity of the Xingu River Basin is still limited, although studies indicate the presence of a very rich biodiversity in the region (ISA, 2012). It is estimated that approximately 600 fish species inhabit the Basin, but only its large rivers have been well surveyed, while studies in the headwater streams are scarce and their fish fauna still little known (Camargo et al., 2004).

Our goal was to investigate the effects of deforestation on headwater stream fish assemblages in the Upper Xingu River Basin. We performed standardized sampling surveys in replicated streams in forested and deforested sites to test the hypotheses that land cover negatively affects the abundance, richness, and taxonomic structure of fish assemblages, and to assess the role of local habitat characteristics on the structure of these assemblages.

\section{Material and methods}

Study area. Field sampling surveys were conducted on Tanguro Ranch, municipality of Querência, eastern state of Mato Grosso, Brazil. By 2013, approximately 60\% percent of the 82,000 ha of the ranch were covered with primary forests. Native vegetation consists of evergreen seasonal closed-canopy forests that are transitional between the ombrophilous rainforests in the North and woody savannas in the South of the Xingu Basin (ISA, 2010). The remaining 40 percent were covered with intensively cultivated soybean fields. Environmental conditions and farming practices in Tanguro Ranch are typical of the southeastern Amazonian agricultural frontier. Regional climate is characterized by high monthly mean temperatures (above $26^{\circ} \mathrm{C}$ ) with distinct dry (May-September) and wet seasons (October-April). The landscape is dominated by broad plateaus gently sloping towards stream channels, and soils are deep and highly permeable (Neill et al., 2013). Land management typically includes slash and burn deforestation in the conversion of forest to pastures, and then tilling, liming, and the extensive use of fertilizers and pesticides in the conversion of pastures to cropland (Schiesari, Grillitsch, 2011). At the study site deforested watersheds were converted from forest to pasture in the early 1980s and from pasture to soybean fields between 2003 and 2008. Streams in converted watersheds presented riparian areas covered mostly by grasses, shrubs and small trees extending 50-200m from stream margins, although Brazilian legislation requires the maintenance of intact vegetation along $30 \mathrm{~m}$ wide riparian buffers in each margin of streams narrower than $10 \mathrm{~m}$.

Sampling protocol. We sampled three first-order streams draining forested watersheds (APP2 and APP2A, tributaries to the Darro River, and APPM, a tributary to the Tanguro River), and of three first-order streams draining deforested watersheds (TAN1, TAN2 and TAN3, tributaries to the Darro River). All streams were deemed relatively independent from each other in that none were tributaries of the same second-order stream. In each stream we sampled three $50 \mathrm{~m}$-long reaches regularly spaced over the first two kilometers $(0,1$ and $2 \mathrm{~km}$ from the source). Our sampling surveys were conducted in the early rainy season in October and November 2013 (Fig. 1).

Each 50-m stream reach was characterized with respect to 11 environmental variables related to basic water quality parameters (temperature, conductivity and $\mathrm{pH}$ ), stream morphology (mean channel depth and width), and habitat structure (canopy cover and proportional substratum cover). Replicated measurements of environmental variables were taken at 6 perpendicular transects crossing stream reaches every $10 \mathrm{~m}$, and their averages were used to characterize each sampling site. Water temperature, conductivity and $\mathrm{pH}$ were measured with electrodes (Eutech Instruments) in the middle of the channel midway through the water column. Channel width was measured as the transversal distance 


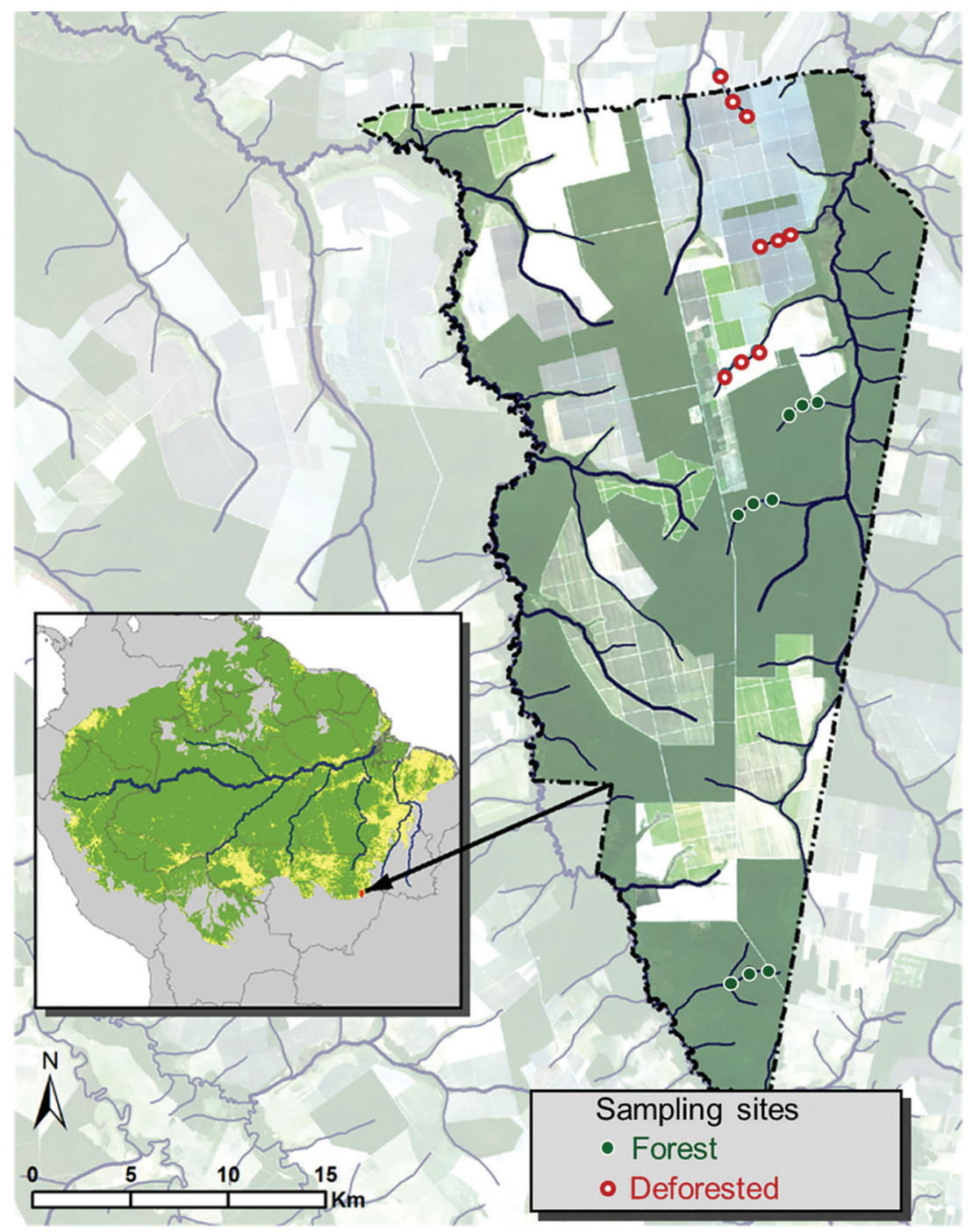

Fig. 1. Location of study area and sampling sites. The inset shows the location of Tanguro Ranch in the southeastern region of the Amazonian Arc of Deforestation, with green representing closed canopy forests, yellow representing deforested areas and uncolored areas representing native savannas. From South to North, streams sampled are APPM, APP2A, APP2, TAN1, TAN2, and TAN3. See the text for details.

between stream margins. Channel depth was measured in three points (at mid-channel, and between mid-channel and each margin) and proportional substratum cover (categorized as coarse benthic organic matter - material larger than $1 \mathrm{~mm}$, including large and small wood and leaf detritus; fine benthic organic matter - material smaller than $1 \mathrm{~mm}$; sand; macrophytes; and grasses) in five points (at mid-channel, at each margin, and between mid-channel and each margin). Canopy cover was estimated by analysis of canopy photos taken at water level in the middle of the channel $(0-24 \%$; $25-$ $49 \%$; 50-74\%; 75-100\%).

Each 50-m stream reach was then subject to a standardized fish sampling effort of 100 person*minutes. During this period the whole area was dipnetted using a $30 \mathrm{~cm}$ diameter net with $1 \mathrm{~mm}$ mesh size. After extensive field trials in the study area, this fishing gear was found to be the most appropriate for fish sampling in the narrow, shallow streams typically rich in large wood, where gill and seine netting were impossible and the low water conductivity $(\sim 10 \mathrm{uS} /$ $\mathrm{cm})$ prevented effective electrofishing. All fish collected were immediately euthanized with benzocaine, preserved in formalin $10 \%$ for $72 \mathrm{~h}$, and stored in ethanol $70 \%$. All specimens were identified to genus or species level and individually weighed on a semi-analytical balance (accuracy of 1 mg, Ohaus Corporation, Pine Brook, NJ, USA). Vouchers were deposited in the ichthyological collection of the Museu de Zoologia da Universidade de São Paulo (catalog numbers 123771-123811).

Data analysis. We used permutational multivariate analysis of variance (PerMANOVA) to test the effect of deforestation on univariate (abundance, biomass, richness) and multivariate (assemblage structure) response variables while accounting for dependence among sampling units (i.e, dependence 
among the three 50-m reaches in each stream). This analysis performs geometric partitioning of variation in the space of any dissimilarity measure and makes statistical inferences using distribution-free permutation algorithms (Anderson, 2001; Anderson, 2017). PerMANOVA can accommodate a wide variety of designs, including nested univariate and multivariate designs consisting of both fixed and random factors (Anderson, 2001; Anderson, 2017). All PerMANOVAs were run using the function "adonis" from the R package "vegan" (Oksanen et al., 2012) after confirming the assumption of homogeneity of variances using the function "betadisper", which is analogous to the Levene's test. To account for the lack of independence among multiple samples within each stream PerMANOVAs were stratified by sampling reach (i.e, permutations were constrained within upstream, middle and downstream reaches, and then quantified between and within land uses). To test the effect of deforestation on fish abundance (in terms of number of individuals and biomass) and richness we conducted univariate PerMANOVAs on the Euclidean distances of the catch-per-unit-effort data. As the number of species in a sample is directly though not linearly related with the number of individuals (Gotelli, Colwell, 2001; Magurran, 2004), we also compared species richness of forest and deforested reaches by means of individual-based rarefaction curves calculated from composite samples of each land cover using the software PAST (Hammer et al., 2001). To test the effect of deforestation on the structure of fish assemblages we conducted a multivariate PerMANOVA on the Bray-Curtis distances of the species relative abundances data to account for differences in sample size between sites.

To assess species relative contributions to differences in assemblage structure we combined two analyses: the non-metric multidimensional scaling (NMDS) to collapse information from multiple species and sites into two axes using the function "metaMDS", and the function "envfit" to calculate and depict species loadings on these two axes (both functions from package vegan). This function performs rank correlations between the species abundances on each site and the scores from each of these on NMDS axis, and a permutation test to assess statistical significance. We used in the metaMDS and envfit functions the Bray-Curtis distances of the $\log (\mathrm{x}+1)$ transformed species abundance data to account for skewed data (dampen large differences between dominant and rare species). Finally, to assess the effects of environmental variables on assemblage structure we conducted a canonical correspondence analysis (CCA) with a forward selection procedure using the function "step" from the R package "stats" (R Core Team, 2017). This function performs a model selection based on Akaike's Information Criterion (AIC) to select the environmental variables that best predict fish assemblage structure. For this analysis, species data were also $\log (\mathrm{x}+1)$ transformed and environmental data were standardized (subtracted the mean and divided by the standard deviation). We used $\mathrm{R}$ version 3.4.3 (R Core Team, 2017).

\section{Results}

Compared to forested stream reaches, deforested stream reaches presented low canopy cover ( $86 v s .10 \%$ on average) and consequently an increase in grasses and macrophytes as opposed to coarse benthic organic matter as substrate cover (Tab. 1). Deforested stream reaches presented in addition higher water temperature and conductivity, and deeper channels.

Tab. 1. Values of mean \pm standard error for the variables measured in the habitat characterization of forest and deforested first-order stream reaches in the Upper Xingu River Basin. $\mathrm{FBOM}=$ fine benthic organic matter; $\mathrm{CBOM}=$ coarse benthic organic matter.

\begin{tabular}{lcc}
\hline Variables & Forested & Deforested \\
\hline Canopy cover $(\%)$ & $86 \pm 2$ & $21 \pm 7$ \\
Temperature $\left({ }^{\circ} \mathrm{C}\right)$ & $25.3 \pm 0.2$ & $27.8 \pm 0.5$ \\
Conductivity $(\mu \mathrm{S} / \mathrm{cm})$ & $5.3 \pm 0.6$ & $18 \pm 3.4$ \\
$\mathrm{pH}$ & $5.64 \pm 0.2$ & $5.97 \pm 0.3$ \\
Width $(\mathrm{m})$ & $1.8 \pm 0.3$ & $2.06 \pm 0.3$ \\
Depth $(\mathrm{cm})$ & $27 \pm 6$ & $45 \pm 8$ \\
Sand $(\%)$ & $7 \pm 4$ & $0 \pm 0$ \\
FBOM $(\%)$ & $40 \pm 6$ & $33 \pm 5$ \\
CBOM $(\%)$ & $51 \pm 6$ & $11 \pm 7$ \\
Grasses $(\%)$ & $0 \pm 0$ & $38 \pm 7$ \\
Macrophytes $(\%)$ & $0 \pm 0$ & $14 \pm 6$ \\
\hline
\end{tabular}

We collected a total of 2504 fishes of 29 species representing 17 families and six orders (Tab. 2). Characiformes was the richest order with 13 species (eight Characidae species, one Crenuchidae, one Curimatidae, two Erythrinidae, and one Lebiasinidae). We also found five species of Siluriformes (one Callichthyidae, one Cetopsidae, two Heptapteridae, and one Loricariidae), four Cichliformes, four Gymnotiformes (one of each family: Gymnotidae, Hypopomidae, Sternopygidae and Rhamphichthyidae), two Cyprinodontiformes (one Rivulidae and one Poecilidae) and one Synbranchiformes (Synbranchidae - Synbranchus marmoratus). The most abundant fish species was the rivulid Melanorivulus megaro$n i$, which represented $\sim 54 \%$ of all individuals collected. This species, together with the cichlid Aequidens michaeli, the lebiasinid Pyrrhulina australis, and the characids Hyphessobrycon mutabilis, Hyphessobrycon loweae, and Moenkhausia phaenota, corresponded to $91 \%$ of all fish collected.

Catch-per-unit effort in terms of number of individuals was twice as high in deforested stream reaches $(189 \pm 26$; mean \pm standard error of the mean) than in forested reaches $\left(89 \pm 14 ; F_{1,17}=11.12, P=0.008\right.$; Fig. 2a). However, fish biomass increased only $\sim 37 \%$ in deforested reaches $(49 \pm$ $7 \mathrm{~g})$ relative to forested $\left(35 \pm 4 \mathrm{~g} ; \mathrm{F}_{1,17}=2.47, \mathrm{P}=0.161\right.$; Fig. 2b). There was no effect of deforestation in fish species richness $\left(\mathrm{F}_{117}=0.14, \mathrm{P}=0.676\right.$; Fig. $\left.2 \mathrm{c}\right)$ : richness varied from 3 to 15 fish species in forested reaches (8 on average), and from 4 to 14 species in deforested reaches $(7$ species on 
average). Rarefaction curves indicated no differences in fish species richness between samples from forest and deforested stream reaches when samples with the same number of individuals were compared (Fig. 3). Altogether, we found 20 species in forest streams and 26 species in deforested streams; sixteen species occurred in both types of habitat, nine were found only in deforested streams and four were found only in forest streams (Tab. 2).

Tab. 2. Number of individuals collected (n) and relative abundance (\%) of fish species in forest and deforested first-order stream reaches in the Upper Xingu River Basin.

\begin{tabular}{|c|c|c|c|c|c|c|}
\hline \multirow{2}{*}{ Order } & \multirow{2}{*}{ Family } & \multirow{2}{*}{ Species } & \multicolumn{2}{|c|}{ Forest } & \multicolumn{2}{|c|}{ Deforested } \\
\hline & & & $\mathrm{n}$ & $\%$ & $\mathrm{n}$ & $\%$ \\
\hline \multirow[t]{13}{*}{ Characiformes } & \multirow[t]{8}{*}{ Characidae } & Astyanax multidens Eigenmann, 1908 & 0 & 0.0 & 48 & 2.8 \\
\hline & & Hyphessobrycon loweae Costa, Géry, 1994 & 68 & 8.5 & 10 & 0.6 \\
\hline & & Hyphessobrycon mutabilis Costa, Géry, 1994 & 70 & 8.7 & 186 & 10.9 \\
\hline & & Hyphessobrycon sp. & 0 & 0.0 & 9 & 0.5 \\
\hline & & Moenkhausia collettii (Steindachner, 1882) & 1 & 0.1 & 3 & 0.2 \\
\hline & & Moenkhausia phaeonota Fink, 1979 & 73 & 9.1 & 83 & 4.9 \\
\hline & & Moenkhausia pirauba Zanata, Birindelli, Moreira, 2010 & 1 & 0.1 & 0 & 0.0 \\
\hline & & Thayeria boehlkei Weitzman, 1957 & 0 & 0.0 & 2 & 0.1 \\
\hline & Crenuchidae & Characidium cf. zebra Eigenmann, 1909 & 0 & 0.0 & 3 & 0.2 \\
\hline & Curimatidae & Steindachnerina sp. & 0 & 0.0 & 1 & 0.1 \\
\hline & \multirow[t]{2}{*}{ Erythrinidae } & Hoplerythrinus unitaeniatus (Spix, Agassiz, 1829) & 3 & 0.4 & 8 & 0.5 \\
\hline & & Hoplias malabaricus (Bloch, 1794) & 11 & 1.4 & 1 & 0.1 \\
\hline & Lebiasinidae & Pyrrhulina australis Eigenmann, Kennedy, 1903 & 13 & 1.6 & 205 & 12.0 \\
\hline \multirow[t]{2}{*}{ Cyprinodontiformes } & Rivulidae & Melanorivulus megaroni (Costa, 2010) & 448 & 55.9 & 923 & 54.2 \\
\hline & Poecilidae & Pamphorichthys sp. & 0 & 0.0 & 21 & 1.2 \\
\hline \multirow[t]{4}{*}{ Gymnotiformes } & Gymnotidae & Gymnotus cf. carapo Linnaeus, 1758 & 31 & 3.9 & 2 & 0.1 \\
\hline & Hypopomidae & Hypopygus lepturus Hoedeman, 1962 & 0 & 0.0 & 15 & 0.9 \\
\hline & Sternopygidae & Eigenmannia trilineata López, Castello, 1966 & 2 & 0.2 & 3 & 0.2 \\
\hline & Rhamphichthyidae & Gymnorhamphichthys rondoni (Miranda Ribeiro, 1920) & 5 & 0.6 & 1 & 0.1 \\
\hline \multirow[t]{4}{*}{ Cichliformes } & \multirow[t]{4}{*}{ Cichlidae } & Aequidens michaeli Kullander, 1995 & 50 & 6.2 & 151 & 8.9 \\
\hline & & Apistogramma sp. & 1 & 0.1 & 2 & 0.1 \\
\hline & & Crenicichla rosemariae Kullander, 1997 & 2 & 0.2 & 1 & 0.1 \\
\hline & & Laetacara sp. & 0 & 0.0 & 3 & 0.2 \\
\hline \multirow[t]{5}{*}{ Siluriformes } & Callichthydae & Megalechis sp. & 2 & 0.2 & 1 & 0.1 \\
\hline & Cetopsidae & Helogenes marmoratus Günther, 1863 & 12 & 1.5 & 0 & 0.0 \\
\hline & \multirow[t]{2}{*}{ Heptapteridae } & Brachyglanis sp. & 5 & 0.6 & 6 & 0.4 \\
\hline & & Rhamdella sp. & 1 & 0.1 & 0 & 0.0 \\
\hline & Loricariidae & Hisonotus acuen Silva, Roxo, Oliveira, 2014 & 0 & 0.0 & 15 & 0.9 \\
\hline Synbranchiformes & Synbranchidae & Synbranchus marmoratus Bloch, 1795 & 2 & 0.2 & 0 & 0.0 \\
\hline
\end{tabular}
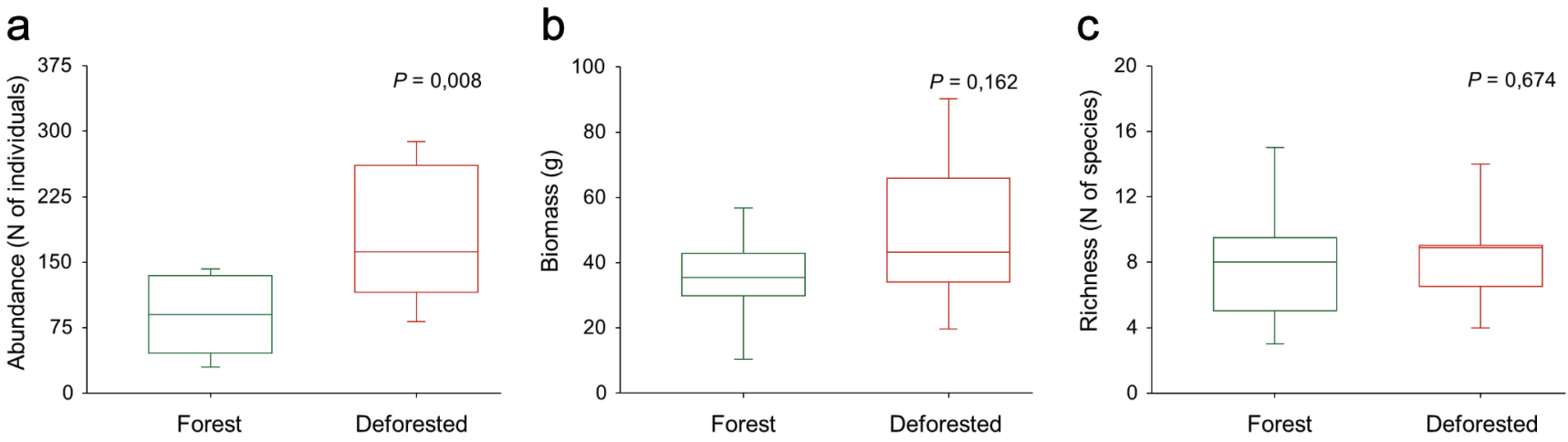

Fig. 2. Catch-per-unit-effort for fishes in forest $(n=9)$ and deforested $(n=9)$ first-order stream reaches in the Upper Xingu River Basin. a. Abundance; b. Biomass; c. Richness. Boxes define the $25^{\text {th }}, 50^{\text {th }}$ (median) and $75^{\text {th }}$ percentiles, whiskers represent the $10^{\text {th }}$ and $90^{\text {th }}$ percentiles. P-values calculated using univariate PerMANOVA. 


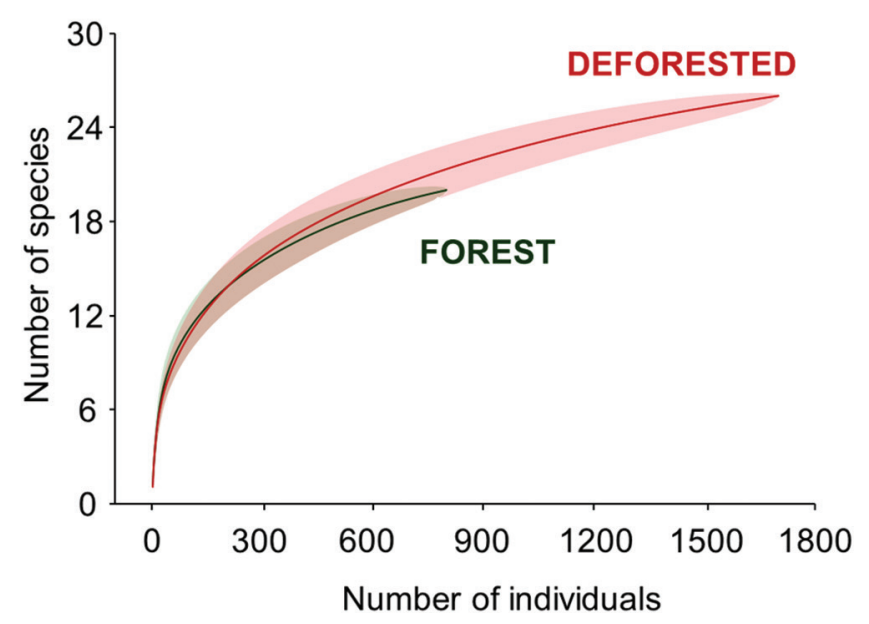

Fig. 3. Individual-based rarefaction curves calculated for fish assemblages collected in forest $(n=9)$ and deforested $(n=9)$ stream reaches in the Upper Xingu River Basin. Colored areas represent $95 \%$ confidence intervals.
We detected a significant multivariate effect of deforestation on the taxonomic structure of fish assemblages $\left(F_{1,17}\right.$ $=2.74, \mathrm{P}=0.01$ ), as further evidenced by the complete segregation of forest and deforested stream reach polygons in the NMDS diagram (Fig. 4). The NMDS diagram is also suggestive of differences in the area of forest and deforested reach polygons, but our analyses found no evidence of heterogeneity of variances between groups $\left(\mathrm{F}_{1,16}=3.65\right.$, $\mathrm{P}$ $=0.07$ ). Six species showed statistically significant loadings on NMDS axes 1 and 2 (Fig. 4; see table of results in the S1 - Available only as online supplementary file accessed with the online version of the article at http://www.scielo. br/ni): Aequidens michaeli, Astyanax multidens, Helogenes marmoratus, Melanorivulus megaroni, Moenkhausia phaeonota, and Pyrrhulina australis. Except for H. marmoratus, which was frequent and relatively abundant in forest streams (12 individuals collected in 6 out of 9 forest stream reaches) but never found in deforested streams, all remaining species were more abundant in deforested stre-

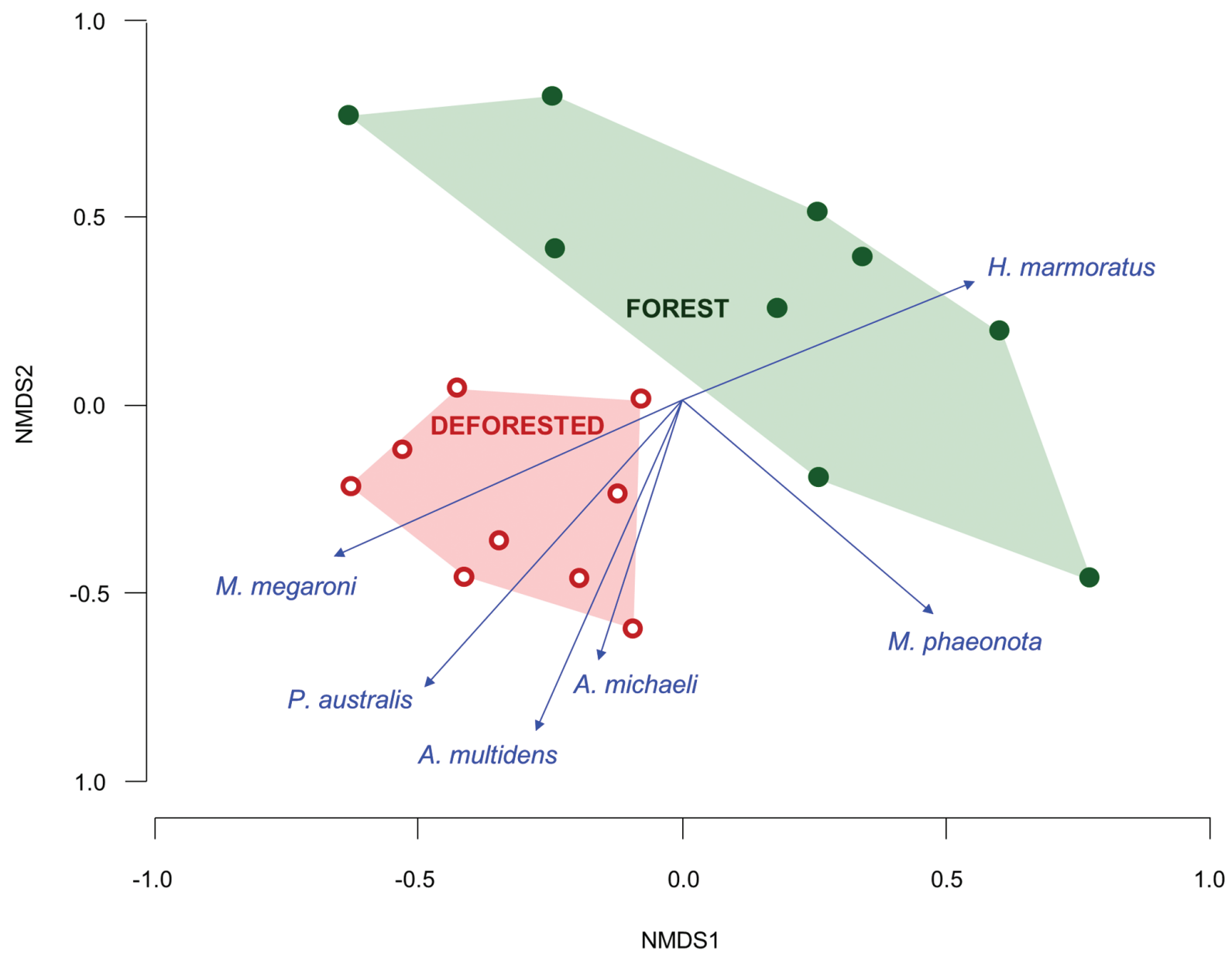

Fig. 4. NMDS diagram of the taxonomic structure of fish assemblages in forest ( $\mathrm{n}=9$; green solid circles and polygon) and deforested ( $\mathrm{n}=9$; red open circles and polygon) stream reaches in the Upper Xingu River Basin. Analysis based on the BrayCurtis distances of 29 fish species $\log (\mathrm{x}+1)$-transformed catch-per-unit-effort. Vectors are species with significant loadings on NMDS axes 1 and 2, and point in the direction of increasing abundance (number of individuals). A. michaeli=Aequidens michaeli; A. multidens = Astyanax multidens; H. marmoratus $=$ Helogenes marmoratus; . megaroni $=$ Melanorivulus megaroni; M. phaeonota = Moenkhausia phaeonota . 
am reaches. $M$. megaroni, $A$. michaeli and $P$. australis were respectively 2,3 , and 15 times more abundant in deforested stream reaches than in forested. Likewise, $A$. multidens was common in deforested stream reaches (48 individuals collected in 7 out of 9 deforested stream reaches) but never observed in the forest streams. The effect of land cover on $M$. phaeonota was more subtle, as abundance in deforested streams was only $13 \%$ greater than in forest streams. Ac- cording to the canonical correspondence analysis (CCA) with forward selection, among measured environmental variables canopy cover was the only significant predictor of fish assemblage structure (Fig. 5; see table of results in the $\mathbf{S 2}$ - Available only as online supplementary file accessed with the online version of the article at http://www. scielo. br/ni), accounting for $\sim 14 \%$ of the variation in species abundance data.

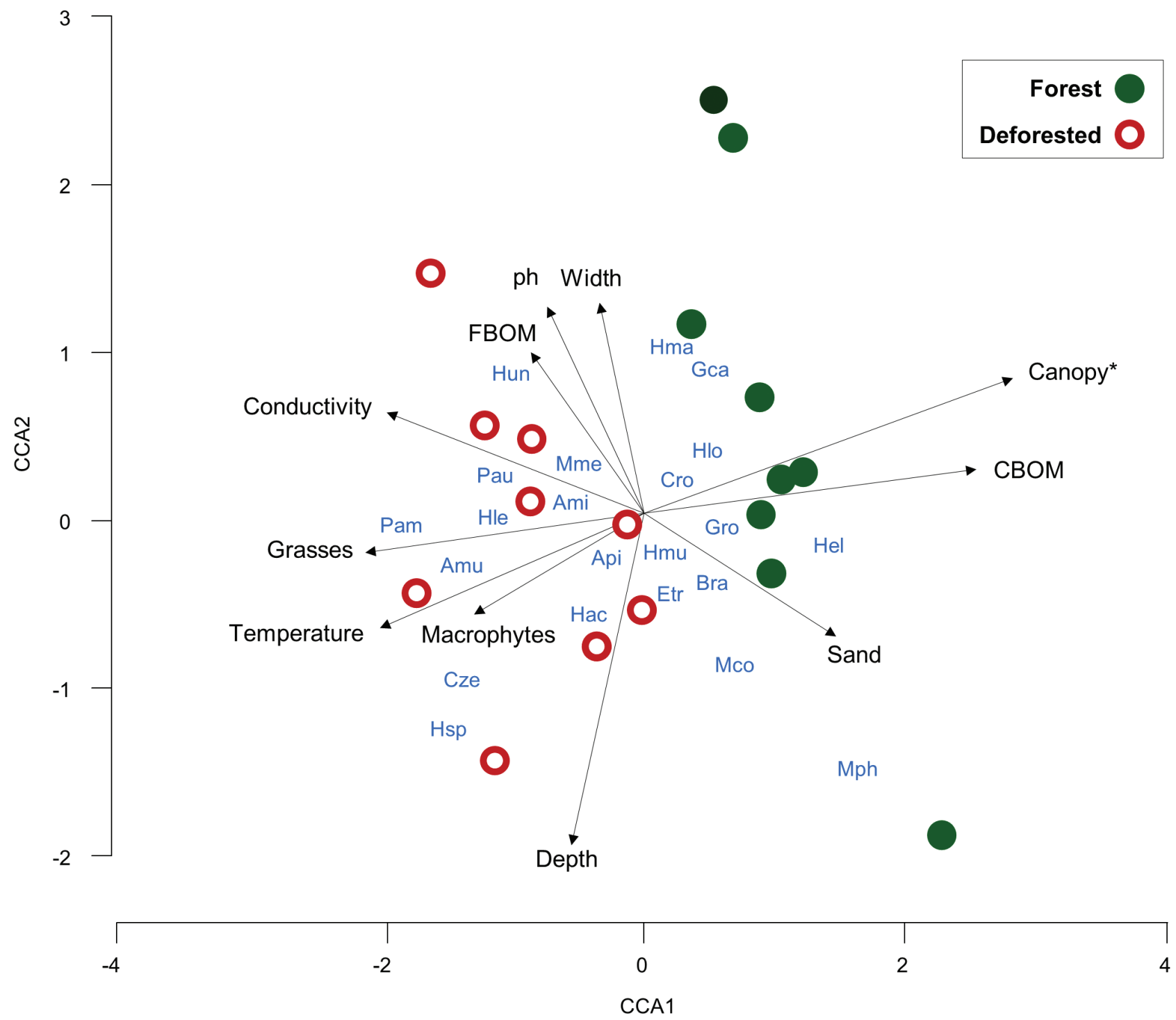

Fig. 5. Diagram of Canonical Correspondence Analysis (CCA) relating 29 fish species (blue letters), 11 environmental variables (black vectors), and 9 sampling sites each in first-order forest streams (solid green circles) and deforested stream reaches (open red circles) in the Upper Xingu River Basin. Species that had only one (singletons), two (doubletons), or three individuals collected were included in the analysis but are not displayed for improved visualization. Environmental variable marked with * was the strongest predictor of fish assemblage's structure. FBOM = fine benthic organic matter; $\mathrm{CBOM}=$ coarse benthic organic matter; Ami $=$ Aequidens michaeli $; \mathrm{Amu}=$ Astyanax multidens $;$ Api $=$ Apistogramma sp.; Bra = Brachyglanis sp.; Cro = Crenicichla rosemariae; Etr $=$ Eigenmannia trilineata $;$ Gro $=$ Gymnorhamphichthys rondoni; $\mathrm{Gca}=$ Gymnotus $\mathrm{cf}$. carapo; Hac = Hisonotus acuen; $\mathrm{Hel}=$ Helogenes marmoratus; Hle = Hypopygus lepturus; Hlo = Hyphessobrycon loweae; $\mathrm{Hma}=$ Hoplias malabaricus; $\mathrm{Hmu}=$ Hyphessobrycon mutabilis; Hsp = Hyphessobrycon sp.; Hun = Hoplerythrinus unitaeniatus; Mme = Melanorivulus megaroni; $\mathrm{Mco}=$ Moenkhausia collettii $;$ Mph $=$ Moenkhausia phaeonota $;$ Pam = Pamphorichthys sp.; Pau = Pyrrhulina australis. 


\section{Discussion}

We demonstrated that deforestation in the Upper Xingu River Basin had a significant effect on stream fish assemblage structure. Deforested stream reaches had 2.1X greater fish abundances and 1.4X greater fish biomasses than reference stream reaches in primary forest. These differences in assemblage structure were largely driven by increases in the abundance of a handful of species, as no influence of deforestation on species richness was observed. Our results therefore reinforce several previous studies demonstrating the pervasive impacts of land cover change on stream fish assemblages (e.g., Burcham, 1988; Dudgeon, 2000; Bojsen, Barriga, 2002; Sutherland et al., 2002; Casatti et al., 2009; Lorion, Kennedy, 2009; Casatti et al., 2015; Brejão et al., 2018; Leal et al., 2018; Leitão et al., 2018). From a faunistic standpoint, the 29 recorded fish species generally conformed to the usual taxonomic pattern for the Neotropical region in general, and the Amazonian Basin in particular (Reis et al., 2003): Characiformes was the order with the largest number of species, followed by Siluriformes and Cichliformes. A noticeable deviance to this pattern was granted by the sharp numerical dominance of a rivulid, Melanorivulus megaroni, very likely a result of our focus on the uppermost reaches of first-order streams (one third of our sampling sites were stream sources).

The changes in fish assemblage structure that we observed might have multiple potential environmental drivers. For example, streams in converted watersheds presented deeper channels, which is recognized as a common result of deforestation (Deegan et al., 2011; de Paula et al., 2018) and an important factor affecting fish species composition (Mendonça et al., 2005; Fernandes et al., 2010). Deforested streams also presented warmer temperatures, a widely reported effect of land cover change on stream ecosystems (Macedo et al., 2013) and a key environmental condition affecting not only fish but potentially all freshwater organisms (Ilha et $a l ., 2018)$. Finally, streams in forested watersheds had dense canopy cover $(>80 \%)$ and bottom substrates covered predominantly by fallen leaves and large wood, while streams in deforested watersheds had canopy covers drastically reduced $(\sim 10 \%)$ and bottom substrates dominated by grasses and macrophytes. Whereas several of these attributes correlated with species patterns in abundance, stream canopy cover was the best predictor of fish assemblages structure, supporting the fundamental importance of the forest on the structuring and functioning of stream ecosystems and their biological communities (e.g., Vannote, 1980; Naiman, Décamps, 1997; Pusey, Arthington, 2003; Schiesari, 2006; Lorion, Kennedy, 2009; Teresa, Casatti, 2010; Casatti et al., 2012).

Headwater streams are strongly influenced by the riparian forest cover, which moderates primary production and water temperatures by shading, and contributes large amounts of allochthonous organic material (large wood, leaves, fruits, seeds, terrestrial insects) that serve as food and habitat for many stream organisms (Vannote, 1980; Angermeier, Karr, 1983; Sweeney, 1993; Naiman, Décamps, 1997; Pusey, Arthington,
2003). The absence of the catfish Helogenes marmoratus in deforested reaches was probably a result of the reduction of stocks of allochthonous materials provided by riparian vegetation (coarse benthic organic material). H. marmoratus uses submerged leaves as habitat for shelter and foraging, and studies suggest that the species may be particularly sensitive to deforestation (Mendonça et al., 2005; Galuch, 2007). Other catfish species that live among and feed on coarse allochthonous vegetal materials, and therefore is highly specialized to use this resource, have also been pointed as potentially more vulnerable to deforestation (Power, 2003; Lujan et al., 2011). Some periphyton-feeding species however can proliferate in deforested sited due to canopy opening and increased primary production (Bojsen, Barriga, 2002). Many fish species from tropical streams have a strong dependence on organic materials provided by the riparian vegetation (Sabino, Zuanon, 1998), and it is likely that species other than H. marmoratus were also negatively affected by deforestation, even if not detected by our statistical analyses. For example, the tetra Hyphessobrycon loweae and the banded knifefish Gymnotus cf. carapo were common in forest streams but became quite rare in deforested ones. Species of the genus Hyphessobrycon feed primarily on terrestrial insects that fall on the water surface and are washed away by the current (Barros, 2012), while G. carapo is a nocturnal predator that inhabits mats of submerged leaves (Mendonça et al., 2005).

Despite declines of forest-dependent species, the most prominent changes in assemblage structure were due to increases, and not to decreases, in species abundances in converted stream reaches. Two species changed from being absent or rare in forests to being common and abundant in deforested reaches (Astyanax multidens and Pyrrhulina australis) whereas three other species doubled or tripled in abundance in deforested reaches (Aequidens michaeli, Melanorivulus megaroni and Hyphessobrycon mutabilis). That is, five of 29 species were largely (89\%) responsible for the observed increase in fish abundances in deforested stream reaches relative to forest stream reaches. Changes in habitat availability, like the increased frequency of small impoundments and shallow micro-habitats in riparian floodplains, are possibly one important cause for these sharp increases in species abundances. In the Upper Xingu River Basin most headwater streams in converted land have at least one impoundment, and usually a series of them (Macedo et al., 2013). The three deforested streams we studied, for example, had 2 to 4 small impoundments within the first 2 kilometers of its courses (between the most upstream and downstream reaches we sampled). Many fish species naturally inhabiting more lacustrine habitats or microhabitats such as backwaters, shallow river margins with low current, and lakes, are reported to be abundant in impoundments throughout Brazil (Castro, Arcifa, 1987; Agostinho et al., 2007, Agostinho et al., 2008). In our study site the cichlid A. michaeli, the characid A. multidens, and the lebiasinid $P$. australis were found to proliferate in impoundments (Ilha, 2015; Schiesari et al., unpublished), and could disperse from these impoundments to the lotic reaches we sampled. 
Availability of shallow micro-habitats in riparian floodplains is also known to affect the abundance of small species, which tend to occupy the shallowest regions of water bodies as a way of reducing risks of predation and dragging (Schiemer et al., 2003). In our study site, area of shallow water in riparian floodplains was found to be twice as large in deforested streams reaches than in forested ones (Ilha, 2015; Schiesari et al., unpublished), probably as result of deforestation on the watershed scale, which promotes water table rising via reduced per-unit-area evapotranspiration and increased contribution of groundwater to stream discharge (Hayhoe et al., 2011). Consequently, the rivulid M. megaroni, which occurs almost exclusively in very shallow micro-habitats, usually in the fringes of water bodies (Costa, 2011; Ilha, 2015), increased in abundance in direct proportion to the increase in area of shallow water in riparian floodplains (Ilha, 2015; Schiesari et al., unpublished). Other studies have also demonstrated that small species can greatly increase in abundance in the shallow areas of streams in deforested areas, usually in grass-dominated environments (Growns et al., 2003; Casatti et al., 2009).

The pronounced increase in fish abundance observed in Upper Xingu deforested stream reaches, surprising at first, is not atypical. Although other studies detected negative effects of deforestation on fish abundance, particularly where deforestation was accompanied by heavy siltation (Jones et al., 1999; Kamdem-Toham, Teugels, 1999), most of the literature suggests that deforestation can lead to increases in total fish abundance due to the proliferation of generalistic species (e.g., Burcham, 1988; Agostinho, Penczak, 1995; Lyons et al., 1995; Bojsen, Barriga, 2002; Casatti et al., 2009; Lorion, Kennedy, 2009; Casatti et al., 2015). Interestingly, the pronounced increase in fish abundance was not directly followed by increases in fish biomass; fish assemblages in deforested stream reaches had 2.1X greater fish abundances but only $1.4 \mathrm{X}$ greater fish biomasses than reference stream reaches in primary forest. This occurred because four of the most common species - M. megaroni, H. mutabilis, M. phaeonota and $H$. loweae - had mean individual body masses $43-55 \%$ lower in deforested streams than in forest streams. Among several potential causes, including resource availability, deforestation-driven stream warming stood out as particularly important. For instance, fishes raised in warmer temperatures, simulating deforested stream conditions, lost mass when compared to fishes raised in cooler temperatures simulating forest stream conditions (Ilha et al., 2018).

Contrary to the clear detectable pattern in fish abundance, no effect of deforestation on fish richness was observed. Again, some studies corroborate the common expectation that the number of fish species declines with deforestation (Lyons et al., 1995; Kamdem-Toham, Teugels, 1999; Dudgeon, 2000; Casatti et al., 2009), but there is a similar amount of evidence suggesting that deforestation may not affect stream fish richness (Lenat, Crawford, 1994; Jones et al., 1999; Bojsen, Barriga, 2002; Sutherland et al., 2002) or even to have a positive effect (Burcham, 1988; Harding et al., 1998; Teresa, Casatti, 2010). Apart from issues related with sampling suf- ficiency, neutral and even positive effects of environmental change on taxonomic richness can sometimes be attributed to biological invasions if the establishment of exotic species offsets native species losses (Sax, Gaines, 2003). Most North American drainages, for example, present more introduced than imperiled or extirpated fish species, suggesting that invaders can in some circumstances increase overall species richness (Gido, Brown, 1999). Similar results were also observed in an agricultural landscape in southeastern Brazil which possess a long history of deforestation and land use (Gerhard, Verdade, 2016). Alternatively, species loss could be masked by extinction debts, i.e, time lags in the species responses to environmental change, often operating in the time range of decades to centuries (e.g., Tilman et al., 1994; Hylander, Ehrlén, 2013; Essl et al., 2015; Brejão et al., 2018). We found no exotic species in our study site, but land conversion in the region occurred less than forty years ago, and therefore it is possible if not likely that stream fish richness we recorded is transitory. Taxonomic richness is still often used as an important metric in community ecology studies and conservation planning, but the deeper meaning of this metric is arguable, especially because it assumes that all species contribute in the same way to ecosystem functioning and does not take into account their functional characteristics and ecological roles (Cadotte et al., 2011). Yet, our study provides a very important contribution documenting the state of stream fish assemblages in the Arc of Deforestation, against which future studies can be compared for the long-term assessment of the consequences of deforestation on biodiversity in the Upper Xingu Basin.

The Amazonian Arc of Deforestation is the most extensive area in the world currently undergoing land conversion and frontier settlement (Brando et al., 2013). In these rapidly changing landscapes, comparative ecological studies as we here present are a priority for providing basic knowledge on species and their distributions, and a historical baseline. Future studies in the Upper Xingu Basin should address the functional characteristics of fish assemblages and the role of riparian forests in sustaining stream ecosystem integrity in converted watersheds, thereby providing the necessary elements to the conservation of this highly relevant fraction of tropical freshwater biodiversity.

\section{Acknowledgments}

We thank Daniel Negri, Ilberto Calado, Nivaldo Carneiro, Darlisson Nunes, Sandro Rocha and Raimundo Quintino for help in the field work, Bruno Abreu for assisting in fish identification, Paul Lefebvre for kindly producing the map, Murilo S. Dias for statistical advice, IPAM and Grupo AMaggi for logistical support, ICMBio for collection permits (17559-2), and FAPESP (PhD Fellowship 2011/20458-6 to PI, and a Young Researcher Award 2008/57939-9 to LS), CNPq (PELD/TANG 23038.000452/2017-16) and CAPES (Post-doctoral Fellowship 88887.136288/2017-00 to PI) for funding this research. 


\section{References}

Agostinho AA, Gomes LC, Pelicice FM. Ecologia e manejo de recursos pesqueiros em reservatórios do Brasil. Maringá (PR): Eduem; 2007.

Agostinho AA, Pelicice FM, Gomes LC. Represamentos e a fauna de peixes neotropicais: impactos e manejo relacionados à diversidade e à pesca. Braz J Biol. 2008; 68(4):1119-32.

Agostinho AA, Penczak T. Populations and production of fish in two small tributaries of the Paraná River, Paraná, Brazil. Hydrobiologia. 1995; 312(3):153-66.

Anderson MJ. A new method for non-parametric multivariate analysis of variance. Austral Ecol. 2001; 26(1):32-46.

Anderson MJ. Permutational multivariate analysis of variance (PERMANOVA). Wiley StatsRef: Statistics Reference Online. 2017; 1-15. Available from https://doi. org/10.1002/9781118445112.stat07841

Angermeier PL, Karr JR. Fish communities along environmental gradients in a system of tropical streams. Environ Biol Fish. 1983; 9(2):117-35.

Barros GG. Ecomorfologia e uso de recursos por quatro espécies sintópicas de peixes (Characidae) em igarapés amazônicos de terra firme, Amazonas, Brasil. [MSc Dissertation on the Internet]. Manaus: Instituto Nacional de Pesquisas da Amazônia; 2012. Available from: Biblioteca Digital INPA. http://bdtd.inpa.gov.br/ handle/tede/ 1675

Bojsen BH, Barriga R. Effects of deforestation on fish community structure in Ecuadorian Amazon streams. Freshwater Biol. 2002; 47(11):2246-60.

Brando PM, Coe MT, DeFries R, Azevedo AA. Ecology, economy and management of an agroindustrial frontier landscape in the southeast Amazon. Phil Trans R Soc B. 2013; 368(1619):20120152. Available from https://doi. org/10.1098/rstb.2012.0152

Brejão GL, Hoeinghaus DJ, Pérez-Mayorga MA, Ferraz SFB, Casatti L. Threshold responses of Amazonian stream fishes to timing and extent of deforestation. Conserv Biol. 2018; 32(4):860-71.

Burcham J. Fish communities and environmental characteristics of two lowland streams in Costa Rica. Rev Biol Trop. 1988; 36(2A):273-85

Cadotte MW, Carscadden K, Mirotchnick N. Beyond species: functional diversity and the maintenance of ecological processes and services. J Appl Ecol. 2011; 48(5):1079-87.

Camargo M, Giarrizzo T, Isaac V. Review of the geographic distribution of fish fauna of the Xingu River basin, Brazil. Ecotropica. 2004; 10:123-47.

Casatti L. Alterações no Código Florestal Brasileiro: impactos potenciais sobre a ictiofauna. Biota Neotrop. 2010; 10(4):31-34.

Casatti L, Ferreira CP, Carvalho FR. Grass-dominated stream sites exhibit low fish species diversity and dominance by guppies: an assessment of two tropical pasture river basins. Hydrobiologia. 2009; 632(1):273-83.

Casatti L, Teresa FB, Gonçalves-Souza T, Bessa E, Manzotti AR, Gonçalves CS, Zeni JO. From forests to cattail: how does the riparian zone influence stream fish? Neotrop Ichthyol. 2012; 10(1):205-14.
Casatti L, Teresa FB, Zeni JO, Ribeiro MD, Brejão GL, CenevivaBastos M. More of the same: high functional redundancy in stream fish assemblages from tropical agroecosystems. Environ Manage. 2015; 55(6):1300-14.

Castro RMC, Arcifa MS. Comunidades de peixes de reservatórios no sul do Brasil. Rev Bras Biol. 1987; 47(4):493-500.

Costa WJEM. Phylogenetic position and taxonomic status of Anablepsoides, Atlantirivulus, Cynodonichthys, Laimosemion and Melanorivulus (Cyprinodontiformes: Rivulidae). Ichthyol Explor Freshwaters. 2011; 22(3):233-49.

Deegan LA, Neill C, Haupert CL, Ballester VR, Krusche AV, Victoria RL, Thomas SM, de Moor E. Amazon deforestation alters small stream structure, nitrogen biogeochemistry and connectivity to larger rivers. Biogeochemistry. 2011; 105(13):53-74.

Dudgeon D. The ecology of tropical Asian rivers and streams in relation to biodiversity conservation. Annu Rev Ecol Syst. 2000; 31(1):239-63.

Essl F, Dullinger S, Rabitsch W, Hulme PE, Pyšek P, Wilson JR, Richardson DM. Delayed biodiversity change: no time to waste. Trends Ecol Evol. 2015; 30(7):375-78.

Fernandes IM, Machado FA, Penha J. Spatial pattern of a fish assemblage in a seasonal tropical wetland: effects of habitat, herbaceous plant biomass, water depth, and distance from species sources. Neotrop Ichthyol. 2010; 8(2):289-98.

Galuch AV. Adaptação de um índice de integridade biótica para igarapés da Amazônia Central, com base em atributos ecológicos da comunidade de peixes. [MSc Dissertation on the Internet]. Manaus: Instituto Nacional de Pesquisas da Amazônia; 2007. Available from: Biblioteca Digital INPA. http://bdtd.inpa.gov.br/handle/tede/1446

Gerhard P, Verdade LM. Stream fish diversity in an agricultural landscape of southeastern Brazil. In: Gheler-Costa C, LyraJorge MC, Verdade LM. Biodiversity in agricultural landscapes of southeastern Brazil. Warsaw, Poland: De Gruyter Open; 2016. p.206-224.

Gido KB, Brown JH. Invasion of North American drainages by alien fish species. Freshwater Biol. 1999; 42(2):387-99.

Gotelli NJ, Colwell RK. Quantifying biodiversity: procedures and pitfalls in the measurement and comparison of species richness. Ecol Lett. 2001; 4(4):379-91.

Growns I, Gerke PC, Astles KL, Pollard DA. A comparison of fish assemblages associated with different riparian vegetation types in the Hawkesbury-Nepean River system. Fisheries Manag Ecol. 2003; 10(4):209-20.

Hammer $\varnothing$, Harper DAT, Ryan PD. PAST: Paleontological statistics software package for education and data analysis. Palaeontol Electron. 2001; 4(1):1-9.

Harding JS, Benfield EF, Bolstad PV, Helfman GS, Jones EBD. Stream biodiversity: the ghost of land use past. Proc Natl Acad Nat Sci USA. 1998; 95(25):14843-47.

Hayhoe SJ, Neill C, Porder S, McHorney R, Lefebvre P, Coe MT, Elsenbeer H, Krusche AV. Conversion to soy on the amazonian agricultural frontier increases streamflow without affecting stormflow dynamics. Glob Change Biol. 2011; 17(5):1821-33. 
Helfman GS. Fish conservation: a guide to understanding and restoring global aquatic biodiversity and fishery resources. Washington (DC): Island Press; 2007.

Hylander K, Ehrlén J. The mechanisms causing extinction debts. Trends Ecol Evol. 2013; 28(6):341-46.

Ilha P. Efeitos da conversão de florestas em áreas agrícolas sobre assembleias de peixes das cabeceiras do rio Xingu. [PhD Thesis on the Internet]. São Paulo: Universidade de São Paulo; 2015. Available from Biblioteca Digital USP. http://www.teses.usp. br/teses/disponiveis/41/41134/tde-30092015-154818/pt-br.php

Ilha P, Schiesari L, Yanagawa FI, Jankowski K, Navas CA. Deforestation and stream warming affect body size of Amazonian fishes. PLoS ONE. 2018; 13(5):e0196560. Available from: http://dx.doi.org/10.1371/journal. pone. 0196560

Instituto Sócio Ambiental (ISA). Fique por dentro: a bacia do rio Xingu em Mato Grosso. Série Cartô Brasil Socioambiental. São Paulo (SP): Instituto Socioambiental; 2010.

Instituto Sócio Ambiental (ISA). De olho na bacia do Xingu. Série Cartô Brasil Socioambiental. São Paulo (SP): Instituto Socioambiental; 2012.

Jones EBD, Helfman GS, Harper JO, Bolstad PV. Effects of riparian forest removal on fish assemblages in Southern Appalachian streams. Conserv Biol. 1999; 13(6):1454-65.

Junk WJ, Piedade MTF. Status of knowledge, ongoing research, and research needs in Amazonian wetlands. Wetl Ecol Manag. 2004; 12(6):597-609.

Kamdem-Toham A, Teugels GG. First data on an Index of Biotic Integrity (IBI) based on fish assemblages for the assessment of the impact of deforestation in a tropical West African river system. Hydrobiologia. 1999; 397:29-38.

Leal CG, Barlow J, Gardner TA, Hughes RM, Leitão RP, Nally RM, Kaufmann PR, Ferraz SFB, Zuanon J, de Paula FR, Ferreira J, Thomson JR, Lennox GD, Dary EP, Röpke CP, Pompeu PS. Is environmental legislation conserving tropical stream faunas? A large-scale assessment of local, riparian and catchment-scale influences on Amazonian fish. J Appl Ecol. 2018; 55(3):1312-26.

Leitão RP, Zuanon J, Mouillot D, Leal CG, Hughes RM, Kaufmann PR, Villéger S, Pompeu PS, Kasper D, de Paula FR, Ferraz SFB, Gardner TA. Disentangling the pathways of land use impacts on the functional structure of fish assemblages in Amazon streams. Ecography. 2018; 41(1):219-32.

Lenat DR, Crawford JK. Effects of land use on water quality and aquatic biota of three North Carolina piedmont streams. Hydrobiologia. 1994; 294(3):185-99.

Lévêque C, Oberdorff T, Paugy D, Stiassny MLJ, Tedesco PA. Global diversity of fish (Pisces) in freshwater. Hydrobiologia. 2008; 595(1):545-67.

Lorion CM, Kennedy BP. Riparian forest buffers mitigate the effects of deforestation on fish assemblages in tropical headwater streams. Ecol Appl. 2009; 19(2):468-79.

Lujan NK, German DP, Winemiller KO. Do wood-grazing fishes partition their niche?: Morphological and isotopic evidence for trophic segregation in Neotropical Loricariidae. Funct Ecol. 2011; 25(6):1327-38.
Lyons J, Navarro-Pérez S, Cochran PA, Santana EC, GuzmánArroyo M. Index of biotic integrity based on fish assemblages for the conservation of streams and rivers in west-central Mexico. Conserv Biol. 1995; 9(3):569-84.

Macedo M, Castello L. State of the Amazon: Freshwater connectivity and ecosystem health. Living Amazon Initiative. Brasília (DF): WWF; 2015.

Macedo MN, Coe MT, DeFries R, Uriarte M, Brando PM, Neill C, Walker WS. Land-use-driven stream warming in southeastern Amazonia. Phil Trans R Soc B. 2013; 368(1619):20120153.

Magurran AE. Measuring biological diversity. Oxford: Blackwell; 2004.

McClain ME, Elsenbeer H. Terrestrial inputs to amazon streams and internal biogeochemical processing. In: McClain ME, Victoria RL, Riche JE, editors. The biogeochemistry of the Amazon Basin. New York (NY): Oxford University Press; 2001. p.185-208.

Mendonça FP, Magnusson WE, Zuanon J. Relationships between habitat characteristics and fish assemblages in small streams of central Amazonia. Copeia. 2005; 2005(4):751-64.

Millennium Ecosystem Assessment. Ecosystems and Human Well-being: Synthesis. Washington (DC): Island Press; 2005.

Naiman RJ, Décamps H. The ecology of interfaces: Riparian zones. Annu Rev Ecol Syst. 1997; 28(1):621-58.

Neill C, Coe MT, Riskin SH, Krusche AV, Elsenbeer H, Macedo MN, McHorney R, Lefebvre P, Davidson EA, Scheffler R, Figueira AM, Porder S, Deegan LA. Watershed responses to Amazon soya bean cropland expansion and intensification. Phil Trans R Soc B. 2013; 368(1619):20120425.

Nepstad D, Soares-Filho BS, Merry F, Lima A, Moutinho P, Carter J, Bowman M, Cattaneo A, Rodrigues H, Schwartzman S, McGrath DG, Stickler CM, Lubowski R, Piris-Cabezas P, Rivero S, Alencar A, Almeida O, Stella O. The end of deforestation in the Brazilian Amazon. Science. 2009; 326(5958):1350-51.

Nepstad DC, Stickler CM, Soares-Filho B, Merry F. Interactions among Amazon land use, forests and climate: prospects for a near-term forest tipping point. Phil Trans R Soc B. 2008; 363:1737-46.

Nogueira C, Buckup PA, Menezes NA, Oyakawa OT, Kasecker TP, Ramos-Neto MB, Silva JMC. Restricted-range fishes and the conservation of brazilian freshwaters. PLoS ONE. 2010; 5(6):e11390.

Oksanen J, Blanchet FG, Friendly M, Kindt R, Legendre P, McGlinn D, Minchin PR, O'Hara RB, Simpson GL, Solymos P, Stevens MHH, Szoecs E, Wagner H. Vegan: Community Ecology Package.

Panday PK, Coe MT, Macedo MN, Lefebvre P, Castanho ADA. Deforestation offsets water balance changes due to climate variability in the Xingu River in eastern Amazonia. J Hydrol. 2015; 523:822-29.

de Paula FR, Gerhard P, Ferraz SFB, Wengerd SJ. Multi-scale assessment of forest cover in an agricultural landscape of Southeastern Brazil: Implications for management and conservation of stream habitat and water quality. Ecol Indic. 2018; 85:1181-91. 
Power ME. Life cycles, limiting factors, and behavioral ecology of four loricariid catfishes in a Panamanian stream. In: Arratia G, Kapoor BG, Chardon M, Diogo R, editors. Catfishes. New Hampshire: Science Publishers; 2003. p.581-600.

Pusey BJ, Arthington AH. Importance of the riparian zone to the conservation and management of freshwater fish: a review. Mar Freshwater Res. 2003; 54(1):1-16.

R Core Team. R: A language and environment for statistical computing. Vienna: R Foundation for Statistical Computing; 2017.

Reis RE, Kullander SO, Ferraris CJ. Check list of the freshwater fishes of South and Central America. Porto Alegre (RS): EDIPUCRS; 2003.

Sabino J, Zuanon J. A stream fish assemblage in central Amazonia: distribution, activity patterns and feeding behavior. Ichthyol Explor Freshwaters. 1998; 8(3):201-10.

Sala OE, Chapin FS, Armesto JJ, Berlow E, Bloomfield J, Dirzo R, Huber-Sanwald E, Huenneke LF, Jackson RB, Kinzi A, Leemans R, Lodge DM, Mooney HA, Oesterheld M, Poff NL, Sykes MT, Walker BH, Walker M, Wall DH. Global biodiversity scenarios for the year 2100. Science. 2000; 287(5459):1770-74.

Sax DF, Gaines SD. Species diversity: from global decreases to local increases. Trends Ecol Evol. 2003; 18(11):561-66. Available from https://doi.org/10.1016/S0169-5347(03)00224-6

Schiemer F, Keckeis H, Kamler E. The early life history stages of riverine fish: ecophysiological and environmental bottlenecks. Comp Biochem Physiol A Mol Integr Physiol. 2003; 133(3):439-49.

Schiesari L. Pond canopy cover: a resource gradient for anuran larvae. Freshwater Biol. 2006; 51(3):412-23.
Schiesari L, Grillitsch B. Pesticides meet megadiversity in the expansion of biofuel crops. Front Ecol Environ. 2011; $9(4): 215-21$.

Schwartzman S, Villas-Boas A, Ono KY, Fonseca MG, Doblas J, Zimmerman B, Junqueira P, Jerozolimski A, Salazar M, Junqueira RP, Torres M. The natural and social history of the indigenous lands and protected areas corridor of the Xingu River basin. Phil Trans R Soc B. 2013; 368(1619):20120164.

Sutherland AB, Meyer JL, Gardiner EP. Effects of land cover on sediment regime and fish assemblage structure in four southern Appalachian streams. Freshwater Biol. 2002; 47(9):1791-805.

Sweeney BW. Effects of streamside vegetation on macroinvertebrate communities of White Clay Creek in eastern North America Proc Acad Nat Sci Philadelphia. 1993; 144(1993):291-340.

Teresa FB, Casatti L. Importância da vegetação ripária em região intensamente desmatada no sudeste do Brasil: um estudo com peixes de riacho. Pan-Am J Aquat Sci. 2010; 5(3):444-53.

Tilman D, May RM, Lehman CL, Nowak MA. Habitat destruction and the extinction debt. Nature. 1994; 371:65-66.

Vannote RL, Minshall GW, Cummins KW, Sedell JR, Cushing CE. The river continuum concept. Can J Fish Aquat Sci. 1980; 37(1):130-37. 